\title{
The Value of Opheleia in Xenophon's Oeconomicus
}

\author{
Dorota Tymura \\ https://orcid.org/0000-0002-7836-9591
}

This article portrays the unique position occupied by the notion of benefit (opheleia) in the philosophy of Xenophon's Socrates. Apparently, opheleia was one of Socrates' most frequently used ethical concepts, and its particular importance was emphasized in Oeconomicus. In Xenophon's dialogue Socrates treats benefit as a value that forms the basis for true friendship, good family relations and especially so in marriage, proper professional attitudes, and thus for all the most important interpersonal contacts. Benefit is also presented as a true spiritual value that shapes the moral behavior of the individual toward himself and others. It holds a prime place in Socrates's ethics. As such a value, it must, however, be based on knowledge and proper moral behavior, especially in line with the demands of enkrateia. It can therefore be ascertained that opheleia, equated also with the good and the beautiful, is strictly tied up with the most important concepts in Socrates' philosophy, such as knowledge, virtue, friendship and moral education and plays a very essential part in his considerations.

Keywords: Socrates, Xenophon, Oeconomicus, benefit, opheleia, knowledge, akrasia

According to Aristotle, Socrates sought to define ethical concepts (Met. 987b), and the Socrates portrayed in Plato's dialogues and Xenophon's writings seems indeed to be engaged in such a project through the exercise of dialectics.

DOROTA TYMURA, doctor, Institute of Philosophy, Maria Curie-Skłodowska University in Lublin, Poland; address for correspondence: Instytut Filozofii UMCS, Pl. Marii Curie-Skłodowskiej 4, PL 20-031 Lublin; e-mail: dorota.tymura@poczta.umcs.lublin.pl 
In an attempt to define these terms, Socrates repeatedly refers to the issue of benefit (ophelia), which, in our contemporary understanding, has negligible ethical connotations. Nevertheless, any careful reader of Xenophon's Socratic writings may discover that ophelia is one of Socrates' most frequently used ethical concepts, and its particular importance has been emphasized in Memorabilia and Oeconomicus. From reading both of these works, it seems that Socrates, when discussing any issue, whether in relation to an activity, an object or a person, focused primarily on the issue of their benefit. Thus, from the point of view of Socratic philosophy, the benefit was a superior ethical concept, which included a number of other fundamental concepts.

In the writings of Xenophon ophelia appears as a value that forms the basis for true friendship, good family relations, especially marriage, proper professional relations, and thus all the most important interpersonal relations. It is treated as a true spiritual value that shapes the moral behavior of the individual toward himself and others. Nevertheless, in his dialectical discussions Socrates does not focus directly on the spiritual dimension of benefit. Such considerations, which were exclusively related to the spiritual sphere and the moral attitude of man, constituted a further stage of his education and upbringing. In the initial phase, however, which acted as a kind of encouragement and to catch the attention of potential students, he focused on theoretical and practical considerations closely related to everyday life, economic and political activity.

The initial discussions on the topic of benefit were therefore mainly concerned with its material and financial aspects, which is perfectly illustrated by the Oeconomicus, a particularly didactic Socratic dialogue. Since the content of the whole work is subordinate to educational goals, it must also include a description of benefit as a spiritual value which is the basis of human existence and proper interpersonal relations. The transition from the material to the spiritual plane is made by Socrates in a rather subtle and thus hardly noticeable way, which results in numerous erroneous interpretations of Oeconomicus, denying it any philosophical meaning. What is important in this regard is the final statement by Socrates himself, which is a typical attempt to define the concept, which clearly shows that he considered the issue of benefit on two levels, preferring its spiritual over its material value. ${ }^{1}$

\footnotetext{
${ }^{1}$ See also Sarah B. Pomeroy, Xenophon, Oeconomicus: A Social and Historical Commentary(Oxford: Clarendon Press, 1994), 19-20.
} 


\section{Oeconomicus as a Didactic Treatise on Benefit (opheleia)}

Xenophon's Oeconomicusis the first literary treatise on "managing one's own estate", i.e. 'home economics' broadly defined. This innovative subject matter gained recognition in the eyes of Aristotle, who in his treatise Economics elaborated in detail on its theoretical basis, while broadening the scope of its considerations. Xenophon, on the other hand, showed it in a more practical form, i.e. the Socratic dialogue, with particular emphasis on its educational aspect. His distinctive discussion on the proper management of an estate based on opheleia in its spiritual and material aspect is combined with the praise of agriculture and its important elements shaping human personality.

We do not find in Oeconomicus purely theoretical considerations, because the main goal of Xenophon's Socrates was to prepare his young students and listeners for practical life in the best possible way. His educational activity was constantly stimulated by the desire to educate young Athenians into rational individuals, whose actions will benefit not only the immediate family but also the entire polity. The Socrates of Xenophon also sees the need for practical example and therefore tries to show his pupils through his own behavior and attitude how to behave in order to become an individual as beneficial as possible to himself and others.

Oeconomicus contains a rare image of Socrates as the educator. This eminent connoisseur of human nature shows his listeners, both directly, through a conversation with Critobulus, and indirectly, through the reminiscence of his own meeting with Ischomachus, what an important role in their lives is played by proper human relations, on which the successful and systematic development of their farm and assets really depends. The farm is made up of people and in order to manage it well, one must first acquire the ability to establish proper interpersonal relations, based principally on mutual opheleia. According to Socrates, the relations must be based primarily on mutual respect and respect for human dignity, whether this applies to the wife, who as a woman has no civil rights, or to the slave who is in charge of the farm, or to a housekeeper. The owner himself must present an appropriate moral attitude, consistently implementing the principle of justice and applying a system of rewards and punishments to people subordinate to him. 
His words and deeds must constitute a unity that undisturbed by changing political or social realities. These considerations echo the philosopher's call for consistency, for keeping his own words and actions in harmony. Socrates himself, being a model of such an attitude, could demand from his listeners, or his pupils, the full realization of it in their lives. At an earlier stage of his upbringing, as shown by Xenophon in Memorabilia, Socrates shaped the moral personality of his listeners, and only then did he try to show them how to maintain the right moral attitude in practical everyday life, calling for it to be constantly strengthened by appropriate actions. In his opinion, the proper acts of man and all his relations with other people must have the support of a well-formed morality. A moral person who acts consistently, manifesting his morality in a unity of words and actions, will not only see himself as a valuable, useful individual, but will also be seen as such by the general public.

We could state that one of the main goals of Socratic education was to shape the personality and develop the mindset of young Athenians to make them able to manage their own estates and be active in politics, since "the management of private concerns differs only in point of number from that of public affairs," (Mem., III 4,12$){ }^{2}$ So insofar as one knows how to rule his own oikos, he could rule all other things well, even the whole polis.

Oikonomia is not an issue that could be strictly associated with Socrates. That is the reason why Xenophon's Oeconomicus is often ignored as a Socratic dialogue. But as Xenophon's other writings clearly show, it was an important subject of discussions in the Socratic circle. For example, in Memorabilia Socrates compares the art of managing an estate to the art of ruling a polis or ten thousand households (Mem., III 4,12; III 6,14; III 9, 10-11). His discussions presented by Xenophon focus on oikonomia as the art of skilled management of an estate, which includes fundamental political and ethical questions. These are in turn the main messages he tries to convey in the discussion to his young interlocutor, Critobulus, who really needs a proper education. ${ }^{3}$

Critobulus was the son of Crito, one of Socrates' closest friends. They all belonged to the same demos, Alopeke, which could have greatly affected their intimacy. As part of the demos, Athenian citizens living in the area met regularly to

\footnotetext{
${ }^{2}$ All citations from Xenophon's Memorabilia are presented in translations made by Marchant, Edgar Cardew. Xenophontis Opera Omnia, vol. II (Oxford: Oxford University Press, 2009).

${ }^{3}$ See also Pomeroy, Xenophon, Oeconomicus: A Social and Historical Commentary, 29-30.
} 
discuss current political or cultic issues. These congregations certainly served to tighten social bonds and interpersonal relations. The exceptionally close and intimate relationship between Socrates and Crito is evident in the last passages of Phaedo (118a), in which the philosopher, as part of his last will, instructs his friend to offer a cock to Asclepius. Crito also, as a person with a particularly close relationship to Socrates, closes his eyes and mouth after death.

His son Critobulus probably joined Socrates' circle at the initiative of Crito himself. Such interpretative guidance can be found in the Euthydemus, which shows that Crito consulted Socrates on the education of his older son, with whom he had some educational problems (306d-307a). In Crito's eyes, the most suitable person for shaping the personality of adolescent Critobulus was certainly Socrates himself. The philosopher fulfilled his friend's request and supported his educational effort with appropriate action. Oeconomicus presents the initial phase of this educational process. We learn from this dialogue that Critobulus needs thorough education and proper instruction because he cannot tame and govern his impulses, especially erotic ones, and has many problems ruling and running his estate profitably. Thus he is in need of instruction typical of Socratic education, in self-sufficiency, the ruling art and virtue, if he really wants to become one of the kaloi kagathoi.

The process of educating Critobulus begins in typically Socratic fashion. The philosopher conducts a discussion exclusively with his young listener, trying to learn about his knowledge base and system of recognized values. In Xenophon, Socrates begins such educational discussions by evoking some universally accepted value, which he tries to define during the conversation. ${ }^{4}$ In the case of Critobulus it is the concept of estate (oikos) and benefit (opheleia). The main educational method used by Socrates in Oeconomicus is his innovative method of elenchus. Its primary purpose is to establish and indicate to the interlocutor the level of his ignorance and to make him reject false beliefs. In addition, Socrates uses a narration of a conversation he had once with Ischomachos to instruct Critobulus about estate management by showing him a man widely recognized as kalos kagathos and his way of life.

${ }^{4}$ Dorota Tymura, Sokrates Ksenofonta (Lublin: Wydawnictwo Uniwersytetu Marii Curie-Skłodowskiej, 2017), 193-198. 
Socrates' approach, noticeable in the choice of the most appropriate educational method and subject matter for a given interlocutor, resembles his discussions with friends presented in Memorabilia and his activity as a good, beneficial friend who tries to help them with both theoretical and practical issues. That is why Oeconomicus could be considered as part of the second book of the Memorabilia, mainly devoted to the concept of friendship. ${ }^{5}$ Socrates chose such ways of educating his friends, because, as emphasized in the Memorabilia, he took great pleasure in having good friends and all his life devoted himself to teaching them all the good he could and to benefiting them as much as possible $(M e m$., I 6,14).

\section{Knowledge as a Basis for Benefit}

Oeconomicus shows that Socrates strictly linked the concept of opheleia with human nature. As he states in his final discussion with Ischomachus "[...] I declare, Ischomachus, on my oath that I believe you, that all men naturally love whatever they think will bring them profit" (Oec., XX 29). So according to Socrates people naturally love such things and activities as can benefit them. Such an approach to opheleia presents it as the most desired value directing human behavior, life choices and general activities, which the more profitable they are, the more people choose them and dedicate their lives to getting them. What is more, men deal with such matters and activities with great pleasure and work to acquire abilities and to improve them constantly. The main aim of such human conduct is to gain a proper benefit (opheleia) both financially and spiritually. Since a man can be benefited by things, but also by other people, like friends who help him in gaining virtue or servants who provide him with good service. But to get it he must acquire and demonstrate adequate knowledge.

In Oeconomicus Socrates links opheleia strictly with knowledge. Such an assumption is already highlighted at the very beginning of the discussion, when Socrates, referring to Kritobulos' identification of good things with property, shows an analogy between the good and benefit (Oec., I, 7-9). Trying to define the con-

${ }^{5}$ Hugh Tredennick and Robert Waterfield, Xenophon. Conversation of Socrates (London: Penguin Books, 1990), 283-284. 
cept of man's estate (oikos) the philosopher looks to conduct, first giving the example of a man who buys a horse but doesn't know how to handle it, which results in considerable loss or even harm. Such a horse can therefore not be the property of this man, because it does not bring him any benefit. The situation is similar with regard to land cultivation and sheep farming, which are loss-making due to the owner's lack of proper knowledge. The lack of this knowledge is precisely what makes the property useless. As we can see, therefore, a farm consists not only of all the things that are useful to its owner, but above all of those for which he has the appropriate knowledge of how to use them. So it is knowledge, episteme, that seems to be the only true possession. Socrates himself confirms this opinion, even stating that "the same things are wealth and not wealth, according as one understands or does not understand how to use them" (Oec., I 10).

Later in the discussion, Socrates refers to Critobulos' statement that an item the owner cannot use will become his property if he sells it. He shows him that he must therefore sell it for something he knows how to use. Otherwise this newly acquired thing will not constitute his property (Oec., I 12). Socrates emphasizes the importance of knowledge by defining the concept of a farm, and Kritobulos, using his practical experience, enriches it with an element of trade, unknowingly falling into the trap set by Socrates. Reacting vigorously to the philosopher's statement, he states that in this light, even money may not be a man's property, and yet it is a common belief that having a significant amount of money is synonymous with wealth.

Xenophon's Socrates underlines a practical dimension of philosophy in his proposed definition of property, which does not include money unless it is used properly and skillfully. The aspect of benefit, which determines the value of a particular action or thing, is raised by Socrates in the next passage of Oeconomicus. "And you, I think, agree with me to this extent that wealth is that from which a man can derive profit," (Oec. I 13). For money can contribute to something harmful, i.e. not beneficial to humans, such as when it is spent on maintaining a hetaira, because on account of her the condition of the human body, the soul and the farm will deteriorate. The problem of possessing a demanding hetaira, commonly known to Athenians of the time, convinces Critobulus of the truth of Socrates' argument that a man's wealth is only what he can use based on his knowledge, which brings him benefit. 
In these extracts of Oeconomicus Socrates emphasizes that the only real wealth for a man is what he can use in the right way, so as to bring him the greatest benefit. But the basis of such use is knowledge, without which no one can make proper use of anything: neither horse, nor land, sheep, or even money. Lack of knowledge causes the things that were supposed to serve the good and to benefit a man, to bring him instead only loss and even contribute to the deterioration of his body and soul. Only knowledge can make bring that wealth which includes material goods, friends and enemies. The only condition is that it be used properly, that is, so that not only those who are close to him but also those who are hostile serve his interests. Such a definition thus makes it possible to consider friends and enemies alike as assets, as long as one is able to handle them so as to benefit from them.

The identical link of benefit and knowledge can be found in the Memorabilia. According to Socrates' belief, by gaining more knowledge we become more beneficial to ourselves and others. The relationship between knowledge and benefit is undisputed for Socrates, and it can be assumed he regarded it as a kind of axiom. Knowledge makes us able to properly assess what is most beneficial at a given moment and direct our action accordingly. We must try to maximize it in order to make the right use of our soul, to help ourselves and others. Knowledge thus appears to be essential to any useful human activity. The knowledge determines a person's benefit, whether he is just a gentleman in his own home or performs important state functions, such as military commanders (Mem., III 3).

\section{Akrasia as a Principal Obstacle to Being Beneficial}

Oeconomicus subsequently shows Critobulus' objection to such a close connection between knowledge and benefit. He draws Socrates' attention to wealthy, well-born Athenians who show no desire to increase their wealth, although they have both the means and, most importantly, knowledge. However, they do not make proper use of it, so even knowledge does not constitute property in their case. Socrates rejects Kritobulos' objection, stating that such people should be equated with slaves, because they are enslaved by wicked rulers, such as laziness, moral weakness and negligence. As we can guess, these are the effects of a lack of 
self-knowledge, self-discipline and that constant work on one's personality which Socrates recommends to his fellow citizens, and indeed demands of them.

Another weakness of Athenians, and a much more serious one according to the philosopher, is their passion for pleasure, whether playing dice or keeping bad company. Over time these seeming pleasures become torments for one who is no longer able to cope with them. Because of them his personality constantly degrades until he is no longer able to do anything useful for himself or for society; he can neither be any opheleia for himself nor for other people.

There are other obstacles to being a beneficial individual, other so-called "wicked rulers", including greed, debauchery, drunkenness and exorbitant ambition. Each of these represents a lack of moderation both in the sensual and emotional sphere destructive of the human body and soul. These 'rulers' are both cunning and cruel, for they enslave their subordinates as long as they are useful to them, young and energetic, but when they grow old abandon them to end their lives in misery. Socrates emphasizes the harm that comes from the lack of composure or restraint, which not only destroys one's body and property, but also degrades the soul. He therefore constantly urges his listeners to fight these excessive lusts and ambitions that "never cease to plague men in body and soul and estate all the time that they have dominion over them," (Oec., I 23).

According to Socrates the biggest obstacle for a man on the way to becoming a beneficial individual is akrasia, the lack of enkrateia. This condition prevents him from getting any opheleia from things, activities or people and also from becoming beneficial for others. Akrasia manifests itself primarily in an excessive adherence to sensual delights, weakening both the body and the proper functioning of the soul. Enkrateia, on the other hand, makes it possible for people to reserve their desires for the right moment, when the satisfaction of these bodily needs will bring them the greatest pleasure.

For Xenophon's Socrates akrasia is that great evil which distracts us from the greatest good, namely wisdom, and pushes us toward its opposite, madness: "As for Wisdom, the greatest blessing, does not incontinence exclude it and drive men to the opposite? Or don't you think that incontinence prevents them from attending to useful things and understanding them, by drawing them away to things pleasant, and often so stuns their perception of good and evil that they choose 
the worse instead of better?" (Mem., IV 5,6). Lack of moderation is the greatest obstacle a person encounters when trying to acquire the knowledge necessary for any benefit.

\section{Opheleia as a Basis for Interpersonal Relationships}

Oeconomicus also presents human relationships based on opheleia, like marriage, friendships or relations between the owner of an estate and his close associates, such as a bailiff and a housekeeper, as closely related to knowledge. They can even be said to be the result of a learning process which makes them profitable not only in their material aspect, but also spiritually beneficial.

A property owner's wife is extremely helpful in good property management. Hence Socrates in the very beginning of his discussion with Critobulus attaches great importance to her proper education, for which her husband is responsible. Her knowledge is considered by the philosopher as a basis of general opheleia for the whole property and all its members (Oec., III 10-13). As he states: "I think that the wife who is a good partner in the household contributes just as much as her husband to its good; because the incomings for the most part are the result of the husband's exertions, but the outgoings are controlled mostly by wife's dispensation. If both do their part well, the estate is increased; if they act incompetently, it is diminished," (Oec., III 15). This may be affirmed by Xenophon himself as well, who in exile took over the lifestyle of the Spartans, among whom the burden of managing the farm rested mainly on women. He may have based this on reflection that Athenian family life should be changed in the direction of closer, more partner-like, marital relations. This interpretation is also supported by the fact that the extensive part of Oeconomicus devoted to the wife's education is a reminiscence of Socrates' encounter with Ischomachus, identified with Xenophon himself, and thus a transmission of the knowledge acquired by the philosopher through a discussion in which he acted as a student rather than a teacher.

As further described in Oeconomicus, the whole process of educating a wife depends mainly on the husband, in accord with his ambitions and assumptions, in order to make their relationship as beneficial as possible. Ischomachus delays its beginning until the day when he sees more courage in his wife towards him, her more open attitude being an essential part of effective education. When discussing 
the issue of the estate Ischomachus emphasizes their equal contribution to its development: "But discretion both in a man and a woman, means acting in such a manner that their possessions shall be in the best condition possible, and that as much as possible shall be added to them by fair and honorable means," (Oec., VII 15).

So, according to Ischomachus, the aim of proper estate management is its just and honest development, not only the constantly increasing prosperity of its owner. He explains to his wife that she should act according to "what the gods made you capable of doing and the law sanctions," (Oec., VII 16). In Ischomachus' view, therefore, such proper development of a estate can only be ensured by acting in accordance with human nature and law. The law mentioned in this passage by the Athenian is probably the so-called "law of the city", an unwritten body of custom which was later partly fixed in the first attempts to codify laws. In his speech there is also an important reference to human nature, which, by its divine origin, dictates proper behavior to both women and men. Its essence is explained in the following way: "And since both the indoor and the outdoor tasks demand labor and attention, God from the first adapted the woman's nature, I think, to the indoor and man's to the outdoor tasks and cares," (Oec., VII 22).

As Ischomachus goes on to state, God created human bodies and souls according to the difference of these activities that are specific to men and women., making the man more resistant to all inconveniences and hardships, and endowing the woman with "a larger portion of affection for new-born babies," and adapting her by nature to nourish them. He also gave her a larger share of fear than the man, "knowing that for protection a fearful disposition is no disadvantage," (Oec., VII 25). On the other hand, the man was given a larger share of courage, because as a person performing his outdoor tasks "he will have to be their defender against any wrong-doer," (Oec., VII 25). Thus God created feminine and masculine bodies and souls for the mutual benefit they are meant to provide for each other in marriage. Stressing the prudence and purposefulness of these divine creations, as men and women appear in the context of this argument, Ischomachos states that since "both have not the same aptitudes, they have the more need of each other, and each member of the pair is the more useful to the other, the one being competent where the other is deficient," (Oec., VII 28). In this way he shows his wife that their community, which is marriage, owes its existence to God himself, and that it exists primarily for their mutual support, which is of mutual benefit. 
The benefit of the wife in charge of the entire house is emphasized by Ischomachus in comparing her to the queen bee controlling the work of her subordinates, remaining in place, whether inside the hive or at home, and sending appropriate groups to do the work outside and supervise the work inside, storing and then distributing the results of these works, ensuring that all resources necessary for the proper functioning of the hive or farm are provided. What is more, just as the queen bee has to look after the young with a view to their future work in the hive, so the lady of the house has to look after the slaves, especially in case of illness. She also needs to educate slaves in skills or abilities they do not possess, such a spinning wool, housekeeping or other services.

All these activities of the wife are intended to significantly increase the material value of the entire estate and its proper functioning, beneficial to all its members. According to Ischomachus, the basis for such a smooth functioning is found in the general order, because "there is nothing so convenient or so good for human beings as order," (Oec., VIII 3). Its usefulness and beauty is illustrated to the wife by the example of the choir, army and farm. The choir, which usually consisted of several dozen people, would completely lose its charm and power to influence the audience if it was in chaos. The basis for its proper functioning must therefore be order, for when choristers "act and chant in an orderly fashion, then those same men at once seem worth seeing and worth hearing," (Oec., VIII 3). Similarly, chaos in the army makes it impossible to wage war efficiently, whereas order makes the army a strong support for friends and a powerful opponent for enemies. Therefore, with the help of his wife, Ischomachus puts the whole house in order, organizing everything according to its purpose and then entrusting her with the general supervision of the order in their house because, as he rightly observes, there will be no use in all of this unless she herself ensures that order prevails everywhere (Oec., IX 14).

The housekeeper who supports an owner's wife in the efficient management of the household must also undergo an appropriate educational process in order to serve the general benefit of the whole estate. Ischomachus emphasizes that she should be characterized by natural predispositions, such as enkrateia in eating, drinking, sleeping and intimate relations with men, good memory and care for the house. He explains that these natural features are a fertile ground for the formation and upbringing of a model housekeeper. 
The whole process of training a housekeeper is aimed at making her as beneficial as possible by fostering in her a strong sense of loyalty. The best way to do so seems to be to share with her all the happy and sad moments arising in the life of her masters, so that she grows closer to them. Her devotion will be even more complete when, having received the relevant knowledge of how to multiply the resources of the estate, she is given the opportunity to benefit from them herself. The last element to be inculcated in the personality of the housekeeper is a sense of justice. The most important contribution to its formation is the careful observation of the conduct of masters who put justice into practice, rewarding and giving esteem to people who follow its precepts. As Ischomachus states: "And further, we put justice into her, by giving more honor to the just than to the unjust, and by showing her that the just live in greater wealth and freedom than the unjust," (Oec., IX 13).

The last important person who contributes to the general benefit of the whole estate is a bailiff. But this too depends on his education and knowledge. This educational process, like others described above, is the responsibility of the owner of the estate. The bailiff performs the important function of acting as his deputy, directing the entire estate in his absence. Just as in the case of a housekeeper, the personality of a bailiff plays a major role in his training. The principal feature to be developed from the beginning is his kindness toward the owner of the estate and members of his family. Otherwise he will not be a source of any benefit, even if he has the appropriate knowledge.

The next stage of the bailiff s education involves shaping his diligence. However, for it to be fully successful, he must have certain natural predispositions similar to a housekeeper. And this is above all an enkrateia that refers both to sensual desires, such as drinking wine or sleeping, and strong emotions, like unhappy love. Such a Socratic approach to enkrateia can also be found in the Memorabilia (IV 5,1; I 5, 4). In both of these works, its achievement is shown as the first stage of human improvement in the pursuit of full self-realization and development, intellectual and moral. In the shaping of human diligence, as Ischomachus points out, the constant care and control of the activities of subordinates and the fair use of the system of rewards and penalties, which has a significant motivational function in this process, play an essential role. As an illustration of his conviction he quotes a well-known story about the "master's eye", which fattens the horse "as speedily as possible" (Oec., XII 20). In his view, a similar relationship also exists 
with regard to many other human affairs and activities. This "master's eye" or care and the proper supervision closely connected with it can make everything much better and more beautiful, or more beneficial. It is only necessary to make the appropriate efforts in this regard and to maintain rigorous consistency.

The next stage of the bailiff's education includes teaching him to manage other people by developing a habit of obedience to his decisions and a sense of justice in him. In this respect, Ischomachus relies on the most important Athenian laws of Dracon and Solon, and the Persian king's code, for in his opinion they not only deliver well-deserved punishments, but more importantly, they benefit righteous, honest people, and not only in the material sense.

Thus, as can be seen, in the training process of both the housekeeper and the bailiff, a decisive role is played by the shaping of a proper moral attitude, the most significant manifestation of which is their just conduct. The general benefit and development of the whole estate comes about through their education. Such a statement resembles Socrates' activity as described in Memorabilia, which made his associates better through moral education, since such education enables people to know and do what is beneficial for themselves and others (Mem., IV $1,5)$.

In conclusion, we can say that the notion of benefit occupied a unique position in Socrates' philosophy. It was even a measure of what is called beautiful and good. No thing, no action nor even a person can be beautiful and good unless it is useful or beneficial. But the degree of this benefit is determined by the knowledge that a person gains about things, actions, behaviors and himself. This knowledge was the necessary condition for making anything or anyone, even the enemy, useful. The scope of it was not only ethics, but also proper management of one's own farm, which, in Socrates' opinion, did not differ much from managing the entire polis. Therefore, everyone should strive hard to acquire such knowledge and to develop it continuously in order to become as beneficial as possible for himself, his family and the state.

Socrates' extremely critical stance towards people who do not have the necessary knowledge and hence cannot be of any benefit is best illustrated by the following passage: "Socrates [...] did say that those who render no service either by word or deed, who cannot help army or city or the people itself in time of need, ought to be stopped, even if they have riches in abundance, above all if they are insolent as well as inefficient," (Mem., I 2,59). These words perfectly reflect the 
aim of Socrates' philosophy, which was to make the Athenians beneficial individuals, both socially and politically, but above all morally, in order to effectively prevent a further deepening of the crisis in morality.

\section{Bibliography}

Anderson, John Kinlich. Xenophon. London: Bristol Classical Press, 2008.

Marchant, Edgar Cardew. Xenophontis Opera Omnia, vol. II. Oxford: Oxford University Press, 2009.

Pomeroy, Sarah B. Xenophon, Oeconomicus: A Social and Historical Commentary. Oxford: Clarendon Press, 1994.

Stevens, John. "Friendship and Profit in Xenophon's Oeconomicus." In The Socratic Movement. Edited by Vander Waerdt Paul, 209-237. Ithaca-London: Cornell University Press, 1994.

Strauss, Leo. Xenophon's Socratic Discourse: An Interpretation of the Oeconomicus. Ithaca: Cornell University Press, 1970.

Taylor, Alfred Edward. Socrates: The Man and His Thought. New York: Doubleday Anchor Books, 1952.

Tredennick, Hugh and Robert Waterfield. Xenophon. Conversation of Socrates. London: Penguin Books, 1990.

Tymura, Dorota. Sokrates Ksenofonta. Lublin: Wydawnictwo Uniwersytetu Marii Curie-Skłodowskiej, 2017.

\section{Streszczenie}

\section{Pożytek (opheleia) jako wartość etyczna w Ekonomiku Ksenofonta}

Celem artykułu jest ukazanie Sokratejskiej opheleia jako istotnej wartości etycznej w życiu człowieka - na podstawie tekstu Ekonomika. Można sądzić, że opheleia była jednym z najczęściej przez Sokratesa używanych pojęć etycznych, a jego szczególna pozycja została uwypuklona w tekście Ekonomika. W dialogu Ksenofonta Sokrates traktuje pożytek jako wartość, która stanowi podstawę prawdziwej przyjaźni, dobrych relacji rodzinnych, w tym szczególnie małżeńskich, właściwych stosunków zawodowych, a więc wszystkich najważniejszych relacji międzyludzkich. Jest on równie ukazany jako prawdziwa wartość duchowa kształtująca zachowanie moralne człowieka zarówno względem samego siebie, jak i innych ludzi, zajmując tym samym czołowe miejsce w etyce Sokratejskiej. Jako taka wartość musi on być jednak oparty na wiedzy i właściwym moralnym postępowaniu, w szczególności w zgodzie z nakazami enkrateia. Dla- 
tego można twierdzić, że opheleia, utożsamiana również z dobrem i pięknem, jest ściśle powiązana z najważniejszymi pojęciami filozofii Sokratesa, takimi jak wiedza, cnota, przyjaźń i moralne wychowanie, i odgrywa $\mathrm{w}$ jego rozważaniach bardzo istotną rolę.

Słowa kluczowe: Sokrates, Ksenofont, Ekonomik, pożytek, opheleia, wiedza, akrasia

\section{Zusammenfassung}

\section{Der Nutzen (Opheleia) als ethischer Wert in Oikonomikos von Xenophon}

Der Artikel setzt sich zum Ziel, Opheleia von Sokrates als wesentlichen ethischen Wert im Leben des Menschen anhand des Textes Oikonomikos aufzuzeigen. Opheleia könnte als einer der von Sokrates am häufigsten verwendeten ethischen Begriffe angesehen werden, wobei sein besonderer Status im Text Oikonomikos hervorgehoben wurde. Im Dialog von Xenophon behandelt Sokrates den Nutzen als einen Wert, der der wahren Freundschaft, guten familiären Beziehungen, insbesondere den ehelichen, richtigen beruflichen Beziehungen, insgesamt den wichtigsten menschlichen Beziehungen zugrunde liegt. Er wird auch als ein wahrer spiritueller Wert dargestellt, der das moralische Verhalten des Menschen gegenüber sich selbst und gegenüber anderen prägt und damit einen führenden Platz in der sokratischen Ethik einnimmt. Als ein solcher Wert muss er jedoch auf Wissen und angemessenem moralischem Verhalten beruhen, insbesondere in Übereinstimmung mit den Geboten der Encrateia. Deswegen kann behauptet werden, dass die auch mit dem Guten und Schönen gleichgesetzte Opheleia, eng mit den wichtigsten Begriffen der Philosophie von Sokrates verbunden ist, wie Wissen, Tugend, Freundschaft und moralische Erziehung, und eine sehr wichtige Rolle in seinen Überlegungen spielt.

Schlüsselworte: Sokrates, Xenophon, Oikonomikos, Nutzen, Opheleia, Wissen, Akrasia

Informacje o autorze:

DOROTA TYMURA, doktor, Instytut Filozofii, Uniwersytet Marii Curie-Skłodowskiej w Lublinie; adres do korespondencji: Instytut Filozofii UMCS, Pl. Marii Curie-Skłodowskiej 4, 20-031 Lublin; e-mail: dorota.tymura@poczta.umcs.lublin.pl 